Jolanta Załęczny

Akademia Finansów i Biznesu Vistula

Filia: Akademia im. Aleksandra Gieysztora w Pułtusku

iD ORCID ID: 0000-0003-0615-410X
OBLICZA WOJNY

TOM $3 \cdot$ MIASTO I WOJNA

ŁÓDŹ2021 • ISBN 978-83-8220-556-5 • s. 153-170

https://doi.org/10.18778/8220-556-5.09

\title{
WARSZAWA W OBLICZU SOWIECKIEGO NAJAZDU W 1920 ROKU
}

Streszczenie. Warszawa, choć nie była bezpośrednio terenem walk podczas wojny 1920 roku, odegrała w niej ważną rolę. Miasto było miejscem funkcjonowania najważniejszych instytucji: Rady Obrony Państwa, Obywatelskiego Komitetu Wykonawczego Obrony Państwa, a przede wszystkim zapleczem działań militarnych i aprowizacyjnych. Społeczność stolicy jak zwykle nie zawiodła. Do punktów werbunkowych do Armii Ochotniczej przybywali kolejni ochotnicy, na rozkaz gen. Hallera zgłaszali się harcerze. Mieszkańcy stolicy organizowali pomoc dla walczących, intensywnie pracowały szpitale. Warszawska ulica była miejscem agitacji oraz propagandy. Temu celowi służyły plakaty i odezwy. Pogrzeby poległych w walkach z bolszewikami stawały się manifestacjami patriotycznymi. O wszelkich działaniach szeroko informowała warszawska prasa, mieszkańcy i obserwatorzy wydarzeń komentowali je w pamiętnikach, a z perspektywy czasu we wspomnieniach. Analiza różnych źródeł pozwala na nakreślenie interesującego obrazu stolicy podczas działań wojennych 1920 roku.

Słowa kluczowe: Warszawa, wojna polsko-bolszewicka, patriotyzm, życie codzienne

Warszawa nie była bezpośrednio terenem walk podczas wojny 1920 r., jednak odegrała w niej ważną rolę nie tylko z uwagi, że była siedzibą władz centralnych. Jako stolica kumulowała w sobie nastroje społeczne i patriotyczne emocje, była sercem narodu, zagrzewała do walki. Warszawska ulica stała się barometrem tych nastrojów.

O wszystkich wydarzeniach szeroko informował warszawska prasa, komentowali wydarzenia mieszkańcy i obserwatorzy życia codziennego. Opisy atmosfery tamtego czasu znalazły odbicie we wspomnieniach z 1920 r. Dla przebiegu wydarzeń znaczenie miały konkretne miejsca na planie stolicy: urzędy, stałe punkty werbunkowe, Cytadela, kościoły, szpitale. 
W roku 1920 Warszawa i warszawiacy byli świadomi rangi wydarzeń. Kiedy armia polska dowodzona przez Piłsudskiego zdobyła Kijów, w stolicy odbyły się uroczystości dziękczynne. Już 18 maja uroczyście powitano Piłsudskiego jak bohatera „wracającego ze szlaku Bolesława Chrobrego”. Jak pisał Jan Szczygielski: „Takiego pochodu nigdy nie widziała Warszawa. Piłsudskiego stojącego na schodach dworca powitał prezydent Piotr Drzewiecki. Potem Naczelnik udał się do kościoła św. Aleksandra. Szpaler wojska i warszawiaków stał wzdłuż Alei Ujazdowskich. Zwycięzca Kijowa był przyjmowany tak, jak przyjmowano w Rzymie konsulów zwycięskich" ${ }^{2}$. Na ulicach miasta obrzucano go kwiatami, wyprzęgano konie z jego powozu, by ciągnąć ekwipaż. Zdaniem Marii Dąbrowskiej: „Było to zjawisko nie do uwierzenia (...). To było tak, jak by mogło być w Grecji albo w Rzymie”3.

Latem 1920 r. zagrożenie ze wschodu narastało. W celu koordynacji działań obronnych powołano Radę Obrony Państwa. W przygotowania do obrony kraju zaangażowały się władze samorządowe stolicy. $\mathrm{Na}$ początku sierpnia została powołana Rada Obrony Stolicy, której przewodniczył wiceprezydent Warszawy Artur Śliwiński ${ }^{4}$. Zdecydowano o wezwaniu całej ludność do czynnego udziału w przygotowaniu do powstrzymania ataku wroga. Dostrzegano potrzebę aprowizacji miasta i podjęcia środków zaradczych przeciwko szalejącej lichwie. Postanowiono wspierać organizacje obywatelskie, które opiekowały się żołnierzami, a także włączyć się w działania mające na celu udzielanie pomocy sanitarnej. Rada organizowała wiece, pochody, zbiórki rzeczy i żywności dla wojska, prowadziła też akcję werbunkową 5 .

Podniosły nastrój udzielał się mieszkańcom Warszawy, choć patriotyczne nastawienie warszawiaków było różnie oceniane. Wincenty Witos uważał, że lubują się oni w krzykliwym patriotyzmie, są powierzchowni, buńczuczni,

1 A. Garlicki, Pierwsze lata Drugiej Rzeczypospolitej. Dzieje narodu i państwa polskiego, t. 3, Warszawa 1989, s. 59.

2 J. SzCZYGIELSKI, Dziennik, Warszawa 2016, s. 83.

3 M. DąBrowsKa, Dzienniki 1914-1965. Tom I: 1914-1925, Warszawa 2009, s. 193.

${ }^{4}$ M.M. DrozDowski, Książe Zdzistaw Lubomirski i Piotr Drzewiecki - pierwsi prezydenci Warszawy, [w:] Warszawa w pierwszych latach Niepodlegtości, red. M.M. DrozDOwsKI, H. SzWANKOWSKA, Warszawa 1998, s. 15.

5 Sprawozdanie z dziatalności Rady Obrony stolicy (sierpień-wrzesień 1920 r.), [w:] Zwycięstwo 1920. Warszawa wobec agresji bolszewickiej, oprac. M.M. DrOZDOwsKI, H. EYCHHORN-SzWANKOWSKA, J. WIECHOWSKI, Paris 1990, s. 257-269. 
lekceważący najważniejsze sprawy ${ }^{6}$. Socjalista Jan Maurycy Borski tak oceniał nastroje w Warszawie w lipcu 1920 r.: „Miasto skondensowanej bezmyślności (...) nałogowego lenistwa i rozwydrzonej wprost filantropii, miasto wiecznych uroczystości, bankietów, pochodów"7. Podobnie krytycznie odnosił się do nastrojów w stolicy Ignacy Daszyński, pisząc: „Warszawa plotkuje, bawi się”, a Władysław Grabski grzmiał w przemówieniu sejmowym: „Ludzie bawią się więcej niż przed wojną, chodzą spokojni, stawiają wymagania, myślą tylko o bogaceniu się"9.

Tymczasem - jeśli Warszawa się bawiła - to cel zabawy był często charytatywny, np. 25 czerwca 1920 r. Polski Biały Krzyż zorganizował na Rynku Starego Miasta zabawę, której celem było zebranie funduszy na potrzeby żołnierzy. Dochód ze spektakli teatralnych czy koncertów przeznaczany był również na potrzeby wojska: „Zabawa Polskiego Białego Krzyża połączyła dwie rzeczy: piękno i pożytek. Piękno, zostawiając wspomnienie estetyczne i barwne, pożytek - gromadząc spory fundusz na potrzeby żołnierza, który dziś piersią własną i krwią nie tylko broni granicy, ale posuwa ją tam, gdzie sięgało dawne dziedzictwo Korony Polskiej"10.

Zainteresowanie wojną wśród warszawiaków osiągnęło apogeum wraz ze zbliżaniem się wojsk wroga do stolicy. Rada Miejska wystosowała odezwę do mieszkańców, w której - apelując do ich patriotycznych uczuć - wzywała „wszystkich obywateli miasta bez względu na zawód, wyznanie i stanowisko, by spełniając swój obowiązek, bądź śpieszyli do szeregów walczących, bądź podejmowali wewnątrz kraju pracę, która wzmocni organizację społeczeństwa i państwa, a pomoże do odparcia wroga"11.

Warto przypomnieć choćby niektóre przykłady aktywności społecznej. Wiele warszawskich firm cukierniczych przestawiło się na produkcję marmolady i sucharów na front, przykładem Fabryka Biszkoptów „Stanisław Fuchs”12.

${ }^{6}$ W. Witos, Moje wspomnienia, t. 2, Paryż 1964, s. 309.

7 „Robotnik” 1920, nr 206, s. 1.

8 I. DASZYŃSKI, Wielki cztowiek w Polsce, Warszawa 1926, s. 20.

9 "Monitor Polski” 1920, nr 145, s. 2.

10 Zabawa na Starym Rynku, „Świat” 1920, nr 26, s. 11.

11 „Dziennik Zarządu m. st. Warszawy” 1920, nr 65, s. 1.

12 Obrona Państwa w 1920 roku. Ksiega sprawozdawczo-pamiątkowa Generalnego Inspektoratu Armii Ochotniczej i Obywatelskich Komitetów Obrony Państwa, red. W. ŚCIBOR-RYLSKI, Warszawa 1923, s. 198-199; J. SzCZEPAŃski, Wojna 1920 roku na Mazowszu i Podlasiu, Warszawa-Pułtusk 1995, s. 98. 
Przekazywano też fundusze na potrzeby walczących. Książe Stanisław Lubomirski, prezes Banku Zjednoczonych Ziem Polskich w Warszawie przekazał na ręce Józefa Piłsudskiego sumę $1 \mathrm{mln}$ marek. Tyle samo wyasygnowało Warszawskie Towarzystwo Ubezpieczen ${ }^{13}$. Na obronę państwa opodatkowało się około 2 tys. osób zatrudnionych w Warszawskiej Dyrekcji Kolejowej. Ofiary pieniężne składali też starsi wiekiem kupcy warszawscy niezdolni do służby wojskowej. Pomoc dla walczącej armii zaoferowali artyści. Związek Artystów Scen Polskich kierowany przez Juliusza Osterwę zorganizował teatr, który wystawiał bezpłatne przedstawienia dla żołnierzy. Natomiast repertuar warszawskich teatrów był dostosowany tematycznie do sytuacji, a żołnierze otrzymywali bezpłatne wejściówki. Dochód z biletów przeznaczano na potrzeby Armii Ochotniczej. Cegiełki rozprowadzał m.in. Robotniczy Komitet Obrony m.st. Warszawy i Profesorskie Koło Opieki nad Żołnierzami.

Kiedy zaczęło się formowanie Armii Ochotniczej, rzemieślnicy wzywani byli do prac na rzecz wojska. Na łamach „Kuriera Warszawskiego” apelowano do krawców, aby zgłaszali się do szycia mundurów. Wielu odpowiedziało na to wezwanie, w warsztatach krawcy szyli mundury, szewcy wyrabiali i naprawiali buty dla żołnierzy. Polski Związek Garbarzy podjął uchwałę o przekazaniu $1 \mathrm{mln}$ marek dla Armii Ochotniczej i wyprodukowaniu butów dla ochotników za drugi milion ${ }^{14}$. Również społeczność żydowska nie pozostała obojętna. Zarząd warszawskiej Gminy Żydowskiej przypominał, że nakazem jest walka w obronie kraju i czas zapomnieć o wszelkich urazach ${ }^{15}$. Zarząd Gminy Starozakonnej przy ul. Grzybowskiej wyasygnował $1 \mathrm{mln}$ marek na zorganizowanie pomocy sanitarnej oraz zadeklarował przekształcenie szkoły rzemieślniczej na fabrykę amunicji1 ${ }^{16}$.

Społeczność Warszawy odpowiedziała na wezwanie do Armii Ochotniczej, najliczniej ruszyła młodzież. Ogólna Konferencja Akademicka wystąpiła 6 lipca 1920 r. z apelem o wstępowanie do ochotniczej służby w Wojsku Polskim, a rektorzy uczelni wydali oświadczenia informujące o gotowości do służby całej społeczności akademickiej. Do dyspozycji Wodza Naczelnego

13 Vide: „Ojczyzna” 1920, nr 35; „Dziennik Poznański” 1920, nr 158, nr 162; A. GrzymaŁA-SIEDLECKI, Cud Wisty. Wspomnienia korespondenta wojennego z 1920 roku, Warszawa 1921, s. 18.

14 „Kurier Warszawski” 1920, nr 195, s. 1-2.

15 „Kurier Warszawski” 1920, nr 190, s. 5.

16 „Kurier Warszawski” 1920, nr 204, s. 4. 
zgłosili się m.in. profesorowie Uniwersytetu Warszawskiego ${ }^{17}$. W odezwie studenci uczelni warszawskich oświadczyli, że:

Praca na wyższych uczelniach ponownie winna ulec zawieszeniu. Dzisiaj bowiem jest jeden przed nami obowiązek: obrona Ojczyzny przed wrogiem. Od tego jedynego obowiązku żaden Polak uchylić się nie może. Koledzy i koleżanki! Nie czas dzisiaj na lekkomyślność, lenistwo, egoizm. Tylko wielki powszechny wysiłek dać nam może zwycięstwo. Do broni! W obronie naszych granic, za całość i niepodległość Rzeczypospolitej! ${ }^{18}$

Własne biura werbunkowe tworzyło Stowarzyszenie Nauczycieli Szkół Średnich. Komitet Nauczycieli Szkół Średnich w Warszawie wezwał wszystkich swoich członków do spełnienia obowiązku wobec Ojczyzny: nauczyciele z kategorią zdrowia A mieli iść na front, z kategorią B - do batalionów obrony Warszawy, z kategorią C - do PCK i biur wojkkowych ${ }^{19}$. W ślad za nauczycielami poszli uczniowie szkół średnich, którzy zaczęli zgłaszać się do punktów werbunkowych ${ }^{20}$.

Maria Dąbrowska pisała w swoim dzienniku pod datą 14 lipca:

naród pod wpływem klęski obudził się nareszcie. Odezwa Rady Obrony Państwa (...) postawiła wszystkich na nogi i pod broń. Tworzy się armia ochotnicza. Oddaliśmy się wszyscy do rozporządzenia władz wojkkowych. Ulice Warszawy rozbrzmiewają marszem ochotników, głosem trąbek, każdego przechodnia na ulicy obowiązują teraz trzy znaki: białego krzyża, czerwonego krzyża i pożyczki państwowej $j^{21}$.

Warszawa stała się zapleczem działań militarnych i miejscem formowania oddziałów ochotniczych. W ciężkich dniach decydujących o losach kraju

17 J. SZCZEPAŃSKI, Spoteczeństwo Polski w walce z bolszewickim najazdem 1920 roku, WarszawaPułtusk 2000, s. 220.

${ }_{18}$ K. Kumaniecki, Odbudowa państwowości polskiej. Najważniejsze dokumenty 1912 - styczeń 1924, Warszawa-Kraków 1924, s. 289.

19 „Kurier Warszawski” 1920, nr 201, s. 4 i nr 210, s. 6.

${ }^{20}$ Z Gimnazjum Władysława IV poszła potem na front grupa uczniów z ks. Ignacym Skorupką. Vide: J. ODZIEMKOwski, Piechota polska w wojnie z Rosją bolszewicka 1919-1920, Warszawa 2010, s. 643. O udziale ochotników - vide: J. ZAŁĘCZNY, Cytadela Warszawska w zapiskach uczestników wojny 1920 roku, [w:] Cytadela Warszawska w 1920 roku, red. T. SKOCZEK, J. ZAŁĘCZNY, Warszawa 2020, s. 81-99.

21 M. DąBROwsKa, op. cit., s. 150. 
dokonała wielkiego wysiłku, wspierając walczących w obronie ojczyzny żołnierzy. Zmobilizowała prawie jedną czwartą ogółu ochotników, w znacznej mierze uczniów i harcerzy. Od 1 lipca do 20 sierpnia do Armii Ochotniczej zgłosiło się ponad 77 tys. ochotników, ponad 20 tys. pochodziło z Warszawskiego Okręgu Generalnego $^{22}$. Była to w dużej mierze młodzież gimnazjalna i akademicka. W szeregach ochotników najliczniejszą grupę stanowili harcerze. Dnia 5 sierpnia 1920 r. Komenda Główna Związku Harcerstwa Polskiego wydała odezwę „Ojczyzna w niebezpieczeństwie”, a w ślad za nią 13 sierpnia rozkaz o ogłoszeniu mobilizacji do Armii Ochotniczej. Deklarowano udział 30 tysięcy druhów ${ }^{23}$. Tylko z chorągwi warszawskiej zgłosiło się około 800 harcerzy.

Harcerze otrzymali rozkaz zameldowania się 17 lipca o godz. $11.00 \mathrm{w}$ Inspektoracie Armii Ochotniczej przy al. Szucha w Warszawie. Stałe punkty werbunkowe zorganizowane zostały ponadto na Politechnice oraz w Gmachu Stowarzyszenia Techników przy ul. Czackiego. Poza tym powstawały lotne punkty zaciągu, takie „biura werbunkowe w postaci stolików, przy których można się było zapisać, stały na rogach ulic”24. Ustawiały się do nich długie kolejki. Jak pisał Adam Grzymała-Siedlecki: „Było coś wspaniałego w tym pochodzie najmłodszych pod sztandary. Jakby wojna krzyżowa, porywająca na nogi wszystkich, kto zdolny jest podźwignąć oręż. A byli wśród nich i tacy, którzy, naprawdę mówiąc, nie dorośli siłami do uciążliwej służby wojskowej”25.

Ochotnicy trafiali do warszawskiej Cytadeli, potem ćwiczyli na Polu Mokotowskim oraz w Rembertowie. Autorzy wspomnień z 1920 r. zgodnie podkreślali, że mieszkańcy stolicy odnosili się bardzo życzliwie do ochotników. „Jeśli żołnierz-ochotnik pojawił się na ulicy, obdarowywany bywał różnymi prezentami w formie paczek, które zawierały słodycze, wędliny, papierosy i przybory do szycia. Jednym słowem, nastał wtedy taki czas, że każdy żołnierz był mile widziany przez społeczeństwo, które rozumiało jak wielkie zagrożenie nadchodzi”"26. Żołnierze mogli liczyć też na bezpłatny posiłek. Dostawali go na każ-

22 Szerzej na ten temat: Obrona Państwa w 1920 roku..., s. 39-50.

${ }_{23}$ T. KATAFIASZ, Formacje wojskowe o rodowodzie harcerskim w wojnie 1920 r., „Słupskie Studia Historyczne” 1998, nr 6, s. 56; H. SzWANKOwsKa, Mtodzież w bitwie warszawskiej, „Kronika Warszawy" 1995, nr 2(98), s. 124.

${ }^{24}$ J. GIERTYCH, Wspomnienia ochotnika 1920 roku, Warszawa 2012, s. 49.

25 A. Grzymata-Siedlecki, op. cit., s. 23.

${ }^{26}$ J. DrążKIEwicz, Pod Ossowem i pod Tarnopolem. Wspomnienia z wojny 1920 r., http://www. bitwawarszawska.pl/193-jozef_drazkiewicz (dostęp: 21 II 2020). 
dej stacji kolejowej. Z inicjatywy Obywatelskiego Komitetu Obrony Państwa jadłodajnie powstały na dworcu Wileńskim, Kaliskim, Brzeskim, Gdańskim, Mareckim oraz obok przystani na Wiśle. Było to możliwe dzięki wsparciu restauratorów warszawskich, którzy dostarczali tam bezpłatnie po 80 obiadów dziennie ${ }^{27}$.

Pierwszym poważnym wydarzeniem w życiu ochotników oraz warszawiaków były uroczystości na pl. Saskim ${ }^{28}$. Uzbrojeni i ubrani w prawdziwe mundury ochotnicy ustawieni zostali w wielkim czworoboku i po wysłuchaniu przemówienia złożyli przysięgę. Był to niezwykle podniosły moment. W trakcie mszy, podczas podniesienia, z Cytadeli rozległa się salwa 20 strzałów armatnich. Opis odnajdujemy w korespondencji Lecha Dymeckiego: „poszliśmy na plac Saski, aby uczestniczyć w obchodach Święta Armii Ochotniczej. Najpierw była msza św. w soborze, potem biskup Gall udzielił błogosławieństwa całej Armii Och. [Ochotniczej - J.Z.] zebranej na placu. Grała orkiestra Namysłowskiego. Potem gen. Haller robił przegląd (...). Następnie pochód ulicami, wśród okrzyków tłumu na cześć A. Och. Potem wróciliśmy do Cytadeli" ${ }^{29}$. Ochotnik Jędrzej Giertych wspominał, że wracali radośni i pełni zapału, bo nareszcie czuli się prawdziwym wojskiem.

Wydarzenie to wywarło także ogromne wrażenie na Charles'u de Gaulle’u, który tak pisał:

Asystuję tej lipcowej niedzieli wielkiej uroczystości patriotycznej na cześć tych ochotników. Dzieje się to na Placu Saskim i, zgodnie ze zwyczajem, zaczyna od mszy wojskowej, odprawionej uroczyście w dawnej rosyjskiej katedrze. Kilka tysięcy ochotników zebrało się na placu. Potem defilują. Wśród nich wielu studentów, kilku robotników, pewna liczba chłopów. Ci ostatni uważali za swój obowiązek przynieść broń. Widać w ich rękach najprzedziwniejsze strzelby. Niektórzy są uzbrojeni w kosy. W czasie mszy, wszyscy ci młodzi ludzie śpiewają słynny hymn „Rotę”. Śpiew biegnie ku niebu, niektóre głosy nacechowane są tą religijną i smutną egzaltacją, która u Słowian cechuje wszystkie ludowe uroczystości. Tak, tu widzimy duszę Polski; żeby ją odkryć trzeba słyszeć i widzieć te masy prostych ludzi ${ }^{30}$.

${ }^{27}$ Obrona Państwa w 1920 roku..., s. 169.

28 J. Szczepański, W Polsce Odrodzonej 1918-1939, [w:] Dzieje Puttuska, t. 2: 1795-1989, red. A. Koseski, J. SZcZepański, Pułtusk 2017, s. 223.

${ }^{29}$ Listy Lecha Dymeckiego $z$ frontu 1920, Warszawa 2004, s. 28.

30 CH. De Gaulle, Bitwa o Wistę: dziennik dziatań wojennych oficera francuskiego, „Zeszyty Historyczne Paryskiego Instytutu Literackiego" 1971, nr 19, s. 5. 
Tego dnia z samochodów sprzedawano obligacje Pożyczki Odrodzenia Polski. Wszystkim udzielał się zapał i podniosły nastrój. „Podniecenie było ogromne. Kochać można w tej Warszawie ten szczery, szeroki, głęboko sięgający prąd narodowy. Ma się wrażenie, że wśród tych ludzi i przy ich pomocy można wszystkie odśrodkowe dążności stłumić i zdusić. Bardziej tu żyw dzisiaj Kiliński, niż pod Racławicami Głowacki. Mniej niż gdziekolwiek jest tu rewolucja niebezpieczna”31 - pisał o Warszawie z dumą Juliusz Zdanowski.

W tych dniach warszawska ulica była miejscem agitacji i propagandy. $\mathrm{Na}$ budynkach umieszczano plakaty zachęcające do wstąpienia do armii. Jak donosił „Tygodnik Ilustrowany” z 24 lipca 1920 r.:

W dniu Armii Ochotniczej prawdziwą sensację na ulicach Warszawy wywołały niesione w pochodzie oryginalne $i$ artystycznie wykonane barwne plakaty o motywach związanych z chwilą obecną i z hasłem, które dzisiaj od góry do dołu przenika społeczeństwo nasze: Do broni! Obecnie te plakaty umieszczano na placach i ulicach Warszawy. Stoją one, biją w oczy i wołają. Są jak głos sumienia. (...) Jedne wstrząsają grozą, inne działają na sentyment, inne wreszcie operują humorem i satyrą; wszystkie zaś podniecają wyobraźnię, brzmią jak pobudka i doskonale spełniają swe zadanie ${ }^{32}$.

Jędrzej Giertych zanotował we wspomnieniach: „Na murach w Warszawie rozklejony był wielki kolorowy afisz o bardzo sugestywnym rysunku. Przedstawiał on cienki mur, na który napiera wielki tłum białych mar, jakby falanga trupów, i usiłuje go przewrócić, a dopiera go od wewnątrz z wysiłkiem dwóch żołnierzy w polskich mundurach. Napis na afiszy brzmiał: »Na front! Wszystko dla frontu! Wszyscy na front!«"33.

Do walki wzywały ulotki agitacyjne i pocztówki patriotyczno-propagandowe. Jedna z nich zawierała strofy wiersza Edwarda Słońskiego pt. Bój o Warszawę. Zdobił je zarys panoramy Starego Miasta z herbem Warszawy według wzoru z XVII w. Wiersz został napisany w momencie zbliżania się do Warszawy wojsk sowieckich zagrażających stolicy państwa. Pod wpływem słów wiersza o mocnym ładunku emocjonalnym do wojska wstąpiło zapewne wielu ochotników.

31 Dziennik Juliusza Zdanowskiego, t. 3: 4 VIII 1919-28 III 1921, Szczecin 2014, s. 188. O obchodach obszernie informował JAN CZEMPIŃSKI na łamach „Kuriera Warszawskiego” 1920, nr 198, s. 1.

32 "Tygodnik Ilustrowany” 1920, nr 30, s. 609.

33 J. GiERTYCH, op. cit., s. 52. 
Działalność agitacyjną na warszawskich ulicach prowadzili przedstawiciele Obywatelskich Komitetów Obrony Państwa, zwani mówcami jednominutowymi. Wzywali napotkane osoby do aktywności na rzecz obrony państwa i do ofiarności ${ }^{34}$. Do warszawiaków apelowali też przedstawiciele władz. Wincenty Witos wzywał ich do obrony miasta i podkreślał, że wspólnie: „muszą stanąć wszyscy obywatele! Stanąć muszą wszyscy do szeregu! Czas najwyższy skończyć ze słowami, skończyć z patriotycznym frazesem! Nadszedł czas twardego czynu!"35. W prasie pisano:

Warszawo przemów! Niech się zespolą dziś wszyscy, niechaj krew obrońców przypieczętuje waśnie i spory, niech jeden wielki cud bohaterstwa znów splendorem owinie dumne białe orły... Niechaj tedy pobiegną wskroś Ciebie nici płomienne. Do broni, do broni wszyscy! Na szańce Warszawy, by bój rozegrać o honor narodu, o cześć Rzeczypospolitej ${ }^{36}$.

Krytykowano postawy zwątpienia, egoizmu i działania na szkodę społeczeństwa ${ }^{37}$. Na łamach „Rzeczypospolitej” Adam Grzymała-Siedlecki pisał:

Boże drogi! Iluż to nicponiów, próżniaków, szlifibruków, tęgich, młodych drabów włóczy się po mieście. Kiedyż tych wyłżygroszów patriotyzmu ogarnie święty wstyd, kiedyż odleci z nich tchórz, odpadnie wygodnictwo. Kiedyż w społeczeństwie nastanie taki porządek obywatelskiej karności - że żaden z nich nie będzie mógł podejść do Polaka, bo Polak się odeń odwróci ${ }^{38}$.

Bo choć społeczeństwo stolicy z powagą odnosiło się do zaistniałej sytuacji, to przecież zdarzały się przypadki zawyżania cen ${ }^{39}$, sporadyczne przypadki zrywania plakatów werbunkowych czy akcje sabotażowe.

W mobilizowanie do walki zaangażowali się też duchowni. Chcąc podnieść na duchu ludność stolicy, wydano zarządzenie podjęcia „publicznych modłów

${ }^{34}$ H. LISIAK, Propaganda obronna w Polsce w rozstrzygajacym okresie wojny polsko-sowieckiej 1920 r., „Dzieje Najnowsze” 1997, nr 4, s. 7.

35 K. Kumaniecki, op. cit., s. 325.

36 Warszawo!, „Wiarus” 1920, nr 34, s. 534.

${ }^{37}$ M.in.: Ocknij się Warszawo!, „Gazeta Poranna” 1920, nr 192; Paskarska rezygnacja, „Mucha” 1920, nr 32; J.M. Borski, Warszawa, „Robotnik” 1920, nr 206; Dość tego!! „Rząd i Wojsko” 1920, nr 31 .

38 A. GrzymąA-Siedlecki, Rozejm? - Pod broń!, „Rzeczpospolita” 1920, nr 57, s. 1.

39 „Kurier Warszawski” z 11 sierpnia informował o bezkarnym wyzysku i podniesieniu cen chleba do potwornej wysokości. 
we wszystkich kościołach. Olbrzymie tłumy ludności chodziły z procesją i chorągwiami przez dwa dni po ulicach Warszawy, śpiewając pieśni i prosząc Boga o zwycięstwo" ${ }^{\prime \prime 0}$. W wielu warszawskich kościołach organizowano modlitwy w intencji zwycięstwa. Dnia 7 lipca ukazał się list pasterski biskupów polskich zawierający apel o wstępowanie do armii oraz o pomoc materialną dla walczących. Na przełomie lipca i sierpnia dało się zauważyć mobilizację religijno-patriotyczną ludności stolicy. Metropolita warszawski zobligował księży do pozostania w swoich parafiach i wspierania wiernych w walce ,z najazdem bolszewickim”¹. Począwszy od 6 sierpnia nakazał w kościołach stolicy odprawianie nowenny, a 8 sierpnia od godz. 7 rano do 17 odbywania całodziennej adoracji Najświętszego Sakramentu. Kulminacyjnym momentem tego dnia była procesja błagalna z relikwiami świętych prowadzona z katedry oraz wszystkich kościołów na plac Zamkowy, połączona z kwestą na potrzeby Armii Ochotniczej. $\mathrm{Na}$ ołtarzu polowym ustawiono relikwie bł. Andrzeja Boboli, patrona Polski, i bł. Władysława z Gielniowa, patrona stolicy. W nabożeństwie wzięło udział około 100 tysięcy warszawiaków ${ }^{42}$.

Do aktywnej postawy w obronie Warszawy i Polski wzywała Rada Miasta. W tym czasie w stolicy aktywnie działały dwie kolejne instytucje: Miejski Komitet Obywatelskiego Komitetu Obrony Państwa oraz - powołana 9 sierpnia rozkazem gubernatora wojskowego Warszawy gen. Franciszka Latinika - Straż Obywatelska m.st. Warszawy. Zorganizował ją samorząd miejski wraz z prawie czterema tysiącami wolontariuszy wywodzącymi się z organizacji społecznych i sportowych. Komendantem na Warszawę mianowano Józefa Szwejcera. Straż dbała o zabezpieczenie strategicznych obiektów publicznych: mostów, wiaduktów, stacji kolejowych ${ }^{43}$.

Dnia 10 sierpnia gen. F. Latinik ogłosił w stolicy stan oblężenia. Na placu Teatralnym odbył się wiec, podczas którego mieszkańcy miasta zachęceni słowami generała, że Warszawę trzeba obronićc ${ }^{44}$, demonstrowali gotowość do działa-

40 W. Witos, op. cit., s. 297.

${ }^{41}$ „Wiadomości Archidiecezjalne Warszawskie” 1920, nr 6-8, s. 164.

${ }^{42}$ M. MAKOwsKi, Kardynat Aleksander Kakowski metropolita warszawski (1913-1938), Warszawa 2015, s. 127; M.M. DROZDOWsKI, Warszawa w obronie Rzeczypospolitej: czerwiec-sierpień 1920, Warszawa 1993, s. 111.

43 Straż Obywatelska 1920-1935, Warszawa 1935, s. 65; J. PYTEL, Udziat Straży Obywatelskich w wojnie polsko-rosyjskiej w lecie 1920 roku, [w:] Bitwa Warszawska 1920 roku w obronie niepodlegtości, red. J. ODZIEMKOwsKi, Warszawa 2005, s. 207-210.

${ }^{44}$ Wiec Rady Obrony Stolicy na pl. Teatralnym, „Kurier Poranny” 1920, nr 218, s. 1. 
nia. Na ulicach zapanowała gorąca atmosfera. „Spokornieli najlekkomyślniejsi, uczuwszy, że wielka pustota jest dzisiaj zbrodnią, że oto rozpoczyna się służba w szeregach Ojczyzny” ${ }^{\not 5}$ - pisał Stanisław Miłaszewski. Mury domów obklejano plakatami agitacyjnymi. Wszędzie pojawiały się hasła: „Na szańce Warszawy”, „Wszyscy pod broń”, „Wszystko dla frontu”, „Kto nie z nami - ten przeciwko nam". Wszędzie dało się odczuć poparcie dla ochotników i pogardę dla tych, którzy nie zgłosili się do punktów werbunkowych. „Młodzieńcom zdatnym, a cywilnym robiono avanie [znieważano] na ulicach" ${ }^{\text {”6 }}$. Pisarz Witold Gombrowicz wspominat:

Cała młodzież zgłaszała się wówczas na ochotnika, wszyscy prawie moi koledzy chodzili już w mundurach, na ulicach pełno było afiszów z palcem wskazującym i z napisami w rodzaju „Ojczyzna cię wzywa”, a młode panienki zapytywały młodzieńców na ulicach: „Dlaczego pan jeszcze nie w wojsku?”7

Natomiast z dumą i szacunkiem odnoszono się do młodych ludzi w mundurach. W swoich zapiskach ochotnicy podkreślali serdeczność warszawiaków. Józef Drąż̇kiewicz, ochotnik z Sierpca, pisał: „Maszerowaliśmy przez Warszawę żegnani kwiatami przez ludność cywilną. Kobiety z nami szły i płakały. Starzy i młodzi mężczyźni odprowadzali nas aż za Warszawę ${ }^{3 * 4}$. Przy dźwiękach orkiestry żegnano 31 lipca wychodzący na front 1. Warszawski Batalion Wartowniczy, który był skoszarowany przy ul. Koszykowej. Warszawiacy ustawili się wzdłuż Krakowskiego Przedmieścia i odprowadzili żołnierzy do Dworca Wschodniego. Obrzucano ich kwiatami, pomarańczami, cukierkami, czekoladą, papierosami w paczkach, a nawet siłą wtykano pieniądze, których żołnierze nie przyjmowali ${ }^{49}$.

W warunkach najwyższego zagrożenia egzamin z odpowiedzialności z powodzeniem zdały działające w Warszawie organizacje społeczne, które włączyły się w akcje mające na celu zapewnienie porządku i bezpieczeństwa, pomoc

45 S. MiŁaszewski, $Z$ dni, w których losy ojczyzny się waża, „Tygodnik Ilustrowany” 1920, nr 31, s. 619 .

${ }^{46}$ Dziennik Juliusza Zdanowskiego..., s. 188. Zdarzały się afisze na domach, informujące, że nie są tam mile widziani młodzi ludzie niesłużący w armii, w kawiarniach ignorowano mężczyzn w cywilnych ubraniach.

47 W. Gombrowicz, Wspomnienia polskie. Wędrówki po Argentynie, Warszawa 1990, s. 26.

48 J. DrĄżKIEWICZ, op. cit.

49 Cyt. za: J. Odziemkowski, op. cit., s. 642. 
uchodźcom, zbieranie i wysyłanie darów dla walczącej armii. Dużą aktywność wykazały: Polski Czerwony Krzyż, Związek Harcerstwa Polskiego, Towarzystwo Gimnastyczne „Sokół”, Warszawskie Towarzystwo Wioślarskie, organizacje kobiece ${ }^{50}$. Wszyscy uczestniczyli w zabezpieczaniu prawobrzeżnej stolicy przed wrogiem: „Przy wyjściu z Pragi - czytamy we wspomnieniach - na rogatkach, widzieliśmy gromady ludzi z rozmaitych sfer, pracujących wspólnie przy kopaniu okopów i zakładaniu drutów kolczastych"

Szczególną aktywność wykazały kobiety należące do Ochotniczej Ligii Kobiet, które organizowały na terenie miasta punkty wydawania żywności, prowizoryczne punkty opatrunkowe. Dostarczały bieliznę, żywność, papierosy, wysyłały na front paczki dla walczących. W akcje charytatywne włączyły się panie $\mathrm{w}$ różnym wieku, $\mathrm{z}$ różnych środowisk nie tylko z Warszawy ${ }^{52}$. Pracowały w szpitalach, w kantynach. Aktywnie odpowiedziały na wezwania Polskiego Białego Krzyża i prowadziły agitację wśród młodzieży. Warszawianki zrzeszone w Ochotniczej Legii Kobiet zamierzały też walczyć z bronią w ręku i nie zaniechały tych planów pomimo zdecydowanego sprzeciwu władz wojskowych. W pierwszych dniach sierpnia powstał kobiecy batalion liniowy liczący 400 ochotniczek, były wśród nich też warszawianki. Batalion miał bronić peryferii Pragi. Kiedy ochotniczki wyruszały 14 sierpnia na pozycje obronne na Grochowie, żegnały je tłumy mieszkańców Warszawy, a kobiety błogosławił Achilles Ratti ${ }^{53}$.

Bezpośrednie zagrożenie stolicy w sierpniu 1920 r. i dochodzące z frontu informacje zdominowały życie miasta. „Gazeta Warszawska” z 14 sierpnia donosiła: „Nad ranem do pogrążonego jeszcze we śnie miasta dolatują odgłosy dział naszych, broniących wrogowi dostępu do stolicy. Gwar miasta nie będzie w stanie niedługo zgłuszyć tych odgłosów i najlekkomyślniejszy z mieszkańców Warszawy nie będzie mógł nie myśleć o walnej bitwie, której wyniki odbiją

${ }^{50}$ Ich bohaterską postawę oddaje treść apelu Polskiego Białego Krzyża opublikowana na łamach „Kuriera Warszawskiego” 1920, nr 186, s. 2-3.

${ }^{51}$ L. MIEDZWIECKI, Wspomnienia z wakacji, cyt. za: I Warszawa nie zawiodta. W 90. rocznice bitwy warszawskiej. Katalog wystawy, Warszawa 2010, s. 57.

52 Co tydzień zgłaszało się tam kilkadziesiąt ochotniczek w różnym wieku. Vide: A.J. CIEŚLIKOWA, Ochotnicza Liga Kobiet 1918-1922, Warszawa 1998.

53 J. SZCZEPAŃSKI, „Gdy wróg puka już do wrót stolicy..... Kobiety polskie wobec najazdu bolszewickiego, [w:] Niepodlegtość z kobieca twarza. Różne przejawy aktywności kobiet w drodze do niepodlegtości (od upadku powstania styczniowego do 1920 roku), red. J. ZAŁĘCZNY, Warszawa 2019, s. 86. 
się na przyszłości całej Europy" ${ }^{\text {‘ }}$. Zmieniły się nastroje, miasto spoważniało. Wyludniły się kawiarnie i restauracje. Pojawiły się nawet głosy, aby zaniechać występów rozrywkowych, zaś 29 lipca Ministerstwo Spraw Wojskowych wydało rozporządzenie zawieszające funkcjonowanie kabaretów i sal tańca.

Potępiano wszelkie nieetyczne czy wręcz niemoralne zachowania. Kiedy ktoś zrywał plakaty agitacyjne czy plakaty Czerwonego Krzyża informujące o epidemii tyfusu plamistego pisano, że „Dobry Polak nie zerwie plakatu, tylko zdrajca! Są ręce jakby płatne przez tegoż wroga, ażeby działały na naszą szkodę"55.

Domagano się wyjaśnień w sprawie nieuczciwych działań: „Firma Bogusław Herse sprzedaje rozetki dla ochotników zrobione z odrobiny wstążeczki białej i amarantowej po 9 marek sztuka. Panie, które wykonywały dla ochotników takie same rozetki, zapewniają, że koszt rozetki wynosi 2 do 3 marek. Sądzić należy, że firma „B. Herse” wyjaśni nam ten nieprawdopodobny fakt pobierania od żołnierza ochotnika podobnie niepomiernych cen" ${ }^{\text {"6 }}$.

Najbardziej jednak martwił wzrost cen: „Paskarze, jak hieny, chwilę dzisiejszą uważają za najlepszą do żeru. Ceny skaczą z godziny na godzinę (...). Cena chleba zdwoiła się w ciągu pół dnia. Kasza podskoczyła do $20 \mathrm{mk}$ za funt. Kartofle chłopi sprzedają po $400 \mathrm{mk}$ korzec, u detalistów (w sklepach po 480)"57.

Warszawa była zapleczem aprowizacyjnym dla wojska, ale musiała też dbać o wyżywienie mieszkańców. Na łamach „Kuriera Warszawskiego” informowano 12 sierpnia, że stolica była dobrze zabezpieczona w żywność. Zapas mąki obliczono na trzy tygodnie, z Poznańskiego jechało 400 wagonów ziemniaków ${ }^{58}$. Aby zapobiec brakom zaopatrzenia ludności cywilnej w podstawowe produkty żywnościowe, magistrat Warszawy wprowadził kartki. Warto dodać, że nie dochodziło w tym czasie w stolicy do niepokojów na tle zaopatrzeniowym. Jednak nie obyło się bez konieczności ograniczeń. Warszawski magistrat powołał w Wydziale Spraw Ogólnych komórki do spraw dystrybucji żywności. Ich zadaniem było dopilnować, aby w mieście nie dochodziło do spekulacji podstawowymi produktami, takimi jak ziemniaki, mąka, cukier, chleb, opał. Dlatego części

54 „Gazeta Warszawska” 1920, nr 221, s. 1.

55 J. RolińsKa, 14 sierpnia 1920 roku. Co dziato się w polskiej stolicy podczas bitwy warszawskiej z bolszewikami?, https://wielkahistoria.pl/14-sierpnia-1920-roku-co-dzialo-sie-w-polskiej-stolicypodczas-bitwy-warszawskiej-z-bolszewikami/ (dostęp: 5 I 2020).

${ }^{56}$ Ibidem.

57 Ibidem.

58 „Kurier Warszawski” 1920, nr 222, s. 3. 
mieszkańcom były wydawane kartki żywnościowe i opałowe, które upoważniały ich do odbioru określonych produktów. Trzeba przyznać, że system działał sprawnie i obyło się bez buntów czy zamieszek ulicznych.

Aprowizacja była niezwykle ważna nie tylko z punktu widzenia mieszkańców stolicy, ale też z uwagi na przybywających uchodźców z podwarszawskich miejscowości, którzy uciekali przed nadciągającym frontem. Na ulicach prawobrzeżnej Warszawy pojawiły się więc wozy załadowane ich dobytkiem. Zdaniem Marii Dąbrowskiej miasto wyglądało ,jak obozowisko albo targowica, pełne było uchodźców, zwłaszcza ziemiańskich, pełne wozów, krów, owiec, koni, bryczek, ludzi" ${ }^{9}$. To z myślą o nich utworzono obóz na Powązkach, gdzie zapewniono im znośne warunki egzystencji. Uchodźcy mogli też korzystać z licznych punktów żywnościowych na terenie miasta.

$\mathrm{Na}$ potrzeby rannych żołnierzy przywożonych z frontu organizowano szpitale. Główny szpital wojskowy zlokalizowano w Szpitalu Ujazdowskim. Składał się z dwóch budowli głównych i kilku pawilonów. Miał 18 oddziałów (w tym 5 dla chorób zakaźnych) i mógł pomieścić nawet ponad 600 osób. W Szpitalu Czerwonego Krzyża przy Smolnej można było ulokować 420 osób $^{60}$. Prowizoryczny szpital działał też na Powiślu. W placówkach medycznych pomagały kobiety - członkinie organizacji społecznych. Poza opieką medyczną umilały też żołnierzom pobyt w szpitalu czytaniem książek i gazet. Akcję tę zorganizowała Czytelnia im. M. Arcta przy Zarządzie Głównym Polskiej Macierzy Szkolnej ${ }^{61}$.

Wyrazem uczuć patriotycznych stały się pogrzeby poległych. Przykładem uroczystości pogrzebowe ks. Ignacego Skorupki, które odbyły się 17 sierpnia na Powązkach. „Tysięczne rzesze odprowadziły jego ciało na wieczny spoczynek. Nad grobem zabrzmiała salwa armatnia"62.

Pokonanie bolszewików na przedpolach Warszawy ocaliło miasto. Byli tego świadomi jego mieszkańcy, którzy zdali w tym czasie trudny egzamin z odpowiedzialności. Postawę warszawiaków docenił Józef Piłsudski, podkreślając, że „Warszawa swoją postawą, spokojem i wiarą ułatwiała żołnierzom zadanie

59 M. DĄBROWSKA, op. cit., s. 251.

60 S. MiŁASZEWSKI, Szpitale wojskowe w stolicy, „Tygodnik Ilustrowany” 1920, nr 34, s. 693-695.

${ }^{61}$ „Kurier Warszawski” 1920, nr 231 (wydanie wieczorne), s. 2.

${ }^{62}$ E. WachnowsKa, Żotnierze Niepodlegtości, Lwów [1939], s. 236. Vide: A.C. ŻAK, Ks. Ignacy Skorupka - symbol obrony Warszawy, [w:] Bitwa warszawska 1920..., s. 231-239; J. ZAŁĘCZNY, Tradycje patriotyczne elementem ksztattowania zbiorowej świadomości historycznej w II Rzeczypospolitej, Warszawa 2017, s. 48-50. 
i pomogła w zwycięstwie. Bowiem walka o Warszawę, walka o miasto - byłą rzeczą najtrudniejszą, gdyż o zwycięstwie stanowiło tu zachowanie obywateli. I Warszawa nie zawiodła" ${ }^{63}$.

Warszawa nie pozostała obojętna na losy mieszkańców innych regionów. Pamiętając, że „Świetne zwycięstwo oręża polskiego oddaliło niebezpieczeństwo zagrażające bezpośrednio Warszawie (...) w poczuciu świętego obowiązku, który na stolicy ciąży, Rada Obrony Stolicy"64 wezwała do tworzenia oddziału ochotniczego, który został 22 sierpnia pociągami przetransportowany do Lwowa.

Przewodniczący Rady Miejskiej Ignacy Balicki na uroczystym posiedzeniu 23 sierpnia z dumą oświadczył, że wsparcie wojsku dał „niezłomny duch narodu i duch tego ludu stołecznego, który jak tylko zdał sobie sprawę z niespodziewanego niebezpieczeństwa, natychmiast stanął cały przy swym żołnierzu, stanął jak żołnierz, lub jak jego pomocnik”. Drugim oparciem było oddanie władzom wojskowym i rządowym wszystkich zorganizowanych sił społecznych z samorządem stolicy na czele, co pozwoliło na podjęcie jednolitych i skoordynowanych działań. Skuteczna i zwycięska obrona Warszawy była możliwa dzięki całej ludności miejskiej, warszawskim ochotnikom i zarządowi municypalnemu pod kierunkiem Rady Obrony Stolicy; dzięki temu zdziałano wiele, nie szczędząc pracy, ofiar a nawet życia ${ }^{65}$.

\section{BIBLIOGRAFIA}

\section{Źródła drukowane}

Dąbrowska M., Dzienniki 1914-1965, t. 1: 1914-1925, Warszawa 2009.

Dziennik Juliusza Zdanowskiego, t. 3: 4 VIII 1919-28 III 1921, Szczecin 2014.

Gaulle de Ch., Bitwa o Wistę dziennik dziatań wojennych oficera francuskiego, „Zeszyty

Historyczne Paryskiego Instytutu Literackiego" 1971, nr 19.

Giertych J., Wspomnienia ochotnika 1920 roku, Warszawa 2012.

Gombrowicz W., Wspomnienia polskie. Wędrówki po Argentynie, Warszawa 1990.

\footnotetext{
63 „Kurier Poranny” 1920, nr 136, s. 1.

${ }^{64}$ Uchwata Rady Obrony Stolicy o pomocy Warszawy dla Lwowa, „Dziennik Zarządu m. Warszawy" 1920, nr 80, s. 4.

${ }^{65}$ „Kurier Warszawski” 1920, nr 234 (wydanie poranne), s. 3.
} 
Grzymała-Siedlecki A., Cud Wisty. Wspomnienia korespondenta wojennego z 1920 roku, Warszawa 1921.

Kumaniecki K., Odbudowa państwowości polskiej. Najważniejsze dokumenty 1912 - styczeń 1924, Warszawa-Kraków 1924.

Listy Lecha Dymeckiego z frontu 1920, Warszawa 2004.

Obrona Państwa w 1920 roku. Ksiegga sprawozdawczo-pamiatkowa Generalnego Inspektoratu Armii Ochotniczej i Obywatelskich Komitetów Obrony Państwa, red. W. Ścibor-Rylski, Warszawa 1923.

Szczygielski J., Dziennik, Warszawa 2016.

Witos W., Moje wspomnienia, t. 2, Paryż 1964.

Zwyciestwo 1920. Warszawa wobec agresji bolszewickiej, oprac. M.M. Drozdowski, H. Eychhorn-Szwankowska, J. Wiechowski, Paris 1990.

\section{Prasa}

„Dziennik Poznański” 1920.

„Dziennik Zarządu m. st. Warszawy” 1920.

„Gazeta Poranna” 1920.

„Gazeta Warszawska” 1920.

„Kurier Poranny” 1920.

„Kurier Warszawski” 1920.

„Monitor Polski” 1920.

„Mucha” 1920.

„Ojczyzna” 1920.

„Robotnik” 1920.

„Rząd i Wojsko” 1920.

„Rzeczpospolita” 1920.

„Świat” 1920, nr 26.

„Tygodnik Ilustrowany” 1920.

„Wiadomości Archidiecezjalne Warszawskie” 1920.

„Wiarus” 1920.

\section{Opracowania}

Cieślikowa A.J., Ochotnicza Liga Kobiet 1918-1922, Warszawa 1998.

Daszyński I., Wielki cztowiek w Polsce, Warszawa 1926. 
Drozdowski M.M., Książ Zdzistaw Lubomirski i Piotr Drzewiecki - pierwsi prezydenci Warszawy, [w:] Warszawa w pierwszych latach Niepodlegtości, red. M.M. Drozdowski, H. Szwankowska, Warszawa 1998, s. 7-16.

Drozdowski M.M., Warszawa w obronie Rzeczypospolitej: czerwiec-sierpień 1920, Warszawa 1993.

Garlicki A., Pierwsze lata Drugiej Rzeczypospolitej. Dzieje narodu i państwa polskiego, t. 3 , Warszawa 1989.

I Warszawa nie zawiodta. W 90. rocznice bitwy warszawskiej. Katalog wystawy, Warszawa 2010.

Katafiasz T., Formacje wojskowe o rodowodzie harcerskim w wojnie 1920 r., „Słupskie Studia Historyczne" 1998, nr 6, s. 49-79.

Lisiak H., Propaganda obronna $w$ Polsce $w$ rozstrzygajacym okresie wojny polsko-sowieckiej 1920 r., „Dzieje Najnowsze” 1997, nr 4, s. 3-25.

Makowski M., Kardynat Aleksander Kakowski metropolita warszawski (1913-1938), Warszawa 2015.

Odziemkowski J., Piechota polska w wojnie z Rosją bolszewicka 1919-1920, Warszawa 2010.

Pytel J., Udziat Straży Obywatelskich w wojniepolsko-rosyjskiej w lecie 1920 roku, [w:] Bitwa Warszawska 1920 roku w obronie niepodlegtości, red. J. Odziemkowski, Warszawa 2005, s. 207-214.

Straż Obywatelska 1920-1935, Warszawa 1935.

Szczepański J., „Gdy wróg puka już do wrót stolicy...”. Kobiety polskie wobec najazdu bolszewickiego, [w:] Niepodlegtość z kobieca twarza. Różne przejawy aktywności kobiet w drodze do niepodlegtości (od upadku powstania styczniowego do 1920 roku), red. J. Załęczny, Warszawa 2019, s. 71-90.

Szczepański J., Spoteczeństwo Polski w walce z bolszewickim najazdem 1920 roku, Warszawa-Pułtusk 2000.

Szczepański J., W Polsce Odrodzonej 1918-1939, [w:] Dzieje Puttuska t. 2: 1795-1989, red. A. Koseski, J. Szczepański, Pułtusk 2017, s. 217-292.

Szczepański J., Wojna 1920 roku na Mazowszu i Podlasiu, Warszawa-Pułtusk 1995.

Szwankowska H., Mtodzież w bitwie warszawskiej, „Kronika Warszawy” 1995, nr 2(98), s. 124.

Wachnowska E., Żotnierze Niepodlegtości, Lwów [1939].

Załęczny J., Cytadela Warszawska w zapiskach uczestników wojny 1920 roku, [w:] Cytadela Warszawska w 1920 roku, red. T. Skoczek, J. Załęczny, Warszawa 2020, s. 81-99.

Załęczny J., Tradycje patriotyczne elementem ksztattowania zbiorowej świadomości historycznej w II Rzeczypospolitej, Warszawa 2017.

Żak A.Cz., Ks. Ignacy Skorupka - symbol obrony Warszawy, [w:] Bitwa warszawska 1920 roku w obronie niepodlegtości, red. Janusz Odziemkowski, Warszawa 2005, s. 231-239. 


\section{Netografia}

Józef Drążkiewicz, Pod Ossowem i pod Tarnopolem. Wspomnienia z wojny 1920 r., http:// www.bitwawarszawska.pl/193-jozef_drazkiewicz (dostęp: 21 II 2020).

Rolińska J., 14 sierpnia 1920 roku. Co dziato się w polskiej stolicy podczas bitwy warszawskiej z bolszewikami?, https://wielkahistoria.pl/14-sierpnia-1920-roku-co-dzialo-sie-wpolskiej-stolicy-podczas-bitwy-warszawskiej-z-bolszewikami/ (dostęp: 5 I 2020).

\section{Jolanta Załęczny}

\section{WARSAW IN THE FACE OF THE BOLSHEVIK INVASION OF 1920}

Summary. Warsaw, although not directly the battlefield during the war of 1920 , played an important role in it. The city was the seat of the most important institutions: the State Defense Council, the Civic Executive Committee for State Defense, and above all, the base for military and provisioning activities. As usual, the capital's community did not disappoint. More volunteers came to the recruitment points for the Volunteer Army, scouts came on the order of General Haller. The inhabitants of the capital organized help for the fighters, hospitals worked intensively. The street in Warsaw was a place of agitation and propaganda. This was the purpose of posters and appeals. Funerals of the fallen in the battles with the Bolsheviks became patriotic manifestations. All activities were widely reported in the Warsaw press, commented on by residents and observers of the events in the diaries, and in retrospect - in the memoirs. The analysis of various sources allows for an interesting picture of the capital to be drawn during the military operations of 1920.

Keywords: Warsaw, the Polish-Bolshevik war, Poland, patriotism, everyday life 